\title{
Staining procedures for the endocrine cells of the upper gastrointestinal mucosa: Light-electron microscopic correlation for the gastrin-producing cell
}

\author{
SERGIO A. BENCOSME AND JUAN LECHAGO \\ From the Department of Pathology, Queen's University, and Kingston General Hospital, Kingston, Ontario, \\ Canada
}

SYNOPSIS Although histochemical, immunohistochemical, and electron microscopic methods have led to the identification of a large variety of endocrine cells in the upper gastrointestinal mucosa, no conventional light microscopic technique capable of the simultaneous identification of these cells has been reported. Such a staining method would be of considerable value to the pathologist as the malfunction of the endocrine cells of the gut, which produce numerous digestive hormones and biogenic amines, is closely related to a number of clinical conditions afflicting man. In this work, after testing three different polychrome staining methods, it has been concluded that a slightly modified Herlant's tetrachrome in tissues fixed in Zenker-formol is the procedure of choice. This method allows the distinction of several different cell types in the upper gastrointestinal mucosa of man and dog and permits the easy identification of the gastrin-producing cells on a routine basis. This identification has been confirmed in the case of two patients with gastrin cell hyperplasia, seen by both light and electron microscopy. Herlant's tetrachrome has proven valuable in the screening of human as well as experimental gastrointestinal tissues and it has been found to be very suitable for recognizing gastrin-producing cell hyperplasias. The usefulness of this method is expected to increase with the establishment of further correlations between the light and electron microscopy of the endocrine cells of the gut.

A large number and a remarkable variety of endocrine cells have been described in the upper gastrointestinal mucosa using histochemistry, immunohistochemistry, and electron microscopy (Capella, Solcia, and Vassallo, 1969; Forssmann, 1970; Forssmann, Orci, Pictet, Renold, and Rouiller, 1969a; Pearse, Coulling, Weavers, and Friesen, 1970; Sasagawa, Kobayshi, and Fujita, 1970; Vassallo, Solcia, and Capella, 1969, 1971). Most of these cells produce either polypeptide hormones (Grossman, 1968) or biogenic amines (Aures, Håkanson, and Owman, 1970; Håkanson, 1970). A nomenclature for the endocrine cells of the gut was adopted at Wiesbaden in 1969, chiefly on the basis of their electron microscopic appearance (Creutzfeldt, 1970). Seven basic types are currently recognized: A cells, purported to produce enteric glucagon; D cells, of unknown function; EC cells, the producers of serotonin; ECL cells, assumed to store some biogenic amines; $G$ cells, the source of Received for publication 10 April 1973. gastrin; $\mathrm{S}$ cells, said to produce secretin; and $\mathrm{L}$ cells, the function of which is still unsettled.

Studies on the endocrine cells of the gut by light microscopy have relied largely on histochemical and immunohistochemical methods each of which allows, as a rule, the identification of only one cell type (Bussolati and Pearse, 1970; Håkanson, 1970; Bussolat,i Capella, Solcia, Vassallo, and Vezzadini, 1971 ; Håkanson, Owman, Sporrong, and Sandler, 1971; Lomský, Langr, and Vortel, 1971; Masson, 1914; McGuigan and Greider, 1971; Pearse, 1968; Polak, Bloom, Coulling, and Pearse, 1971a, b; Solcia, 1972; Solcia, Vassallo, and Capella, 1970a). After using these methods and/or electron microscopy quantitative as well as qualitative changes have been noted in the endocrine cells of the gut from patients with a number of clinical conditions. These include: (a) carcinoid tumours associated with typical (Williams and Sandler, 1963; Black, 1968; Soga and Tazawa, 1971) and atypical (Sandler and Snow, 1958; Campbell, Gowenlock, Platt, and Snow, 1963) 
carcinoid syndrome, as well as peptic ulcers (Black and Haffner, 1968); (b) states of gastric acid hypersecretion, such as the Zollinger-Ellison syndrome with intestinal gastrinoma (Oberhelman, Nelson, Johnson, and Dragstedt, 1961; Thompson, Hirose, Lemmi, and Davidson, 1968), some patients with acromegaly (Pearse and Bussolati, 1970; Creutzfeldt, Arnold, Creutzfeldt, Feurle, and Ketterer, 1971), hyperparathyroidism (Pearse and Bussolati, 1970; Polak, Bussolati, and Pearse, 1971c) retained antrum (Solcia, 1972) and a percentage of peptic ulcers (Solcia, Capella, and Vassallo, 1970b; Lechago and Bencosme, 1973); and (c) states of gastric hyposecretion, such as pernicious anaemia (Rubin, 1969; Creutzfeldt et al, 1971; Polak, Coulling, Doe, and Pearse, 1971d). No light microscopic technique capable of demonstrating simultaneously the various endocrine cell types of the digestive mucosa has been reported so far. Such techniques should enable the pathologist to study biopsy and surgical specimens in more detail than has been possible heretofore. It would also be of considerable value to the researcher dealing with these endocrine cells in human as well as experimental subjects.

To develop such a procedure we have tested a number of polychrome techniques known to be capable of distinguishing various polypetide-producing cell types in other endocrine glands. Modifications of Masson's trichrome and Gomori's chromealum-haematoxylin have been successfully used to stain the cells of the pancreatic islets (Bencosme, 1952), while Herlant's tetrachrome has proven to be adequate in discriminating among a large variety of cell types in the hypophysis (Herlant, 1960; Kraicer, Herlant, and Duclos, 1967). In the present work an assessment of the value and limitations of these staining techniques will be made using samples of human and canine upper gastrointestinal mucosa. In addition, correlations will be attempted between the polychrome methods mentioned above and some silver impregnation procedures traditionally used to identify endocrine cells in the gut (Masson, 1914) and the pancreas (Hellerström and Hellman, 1960).

Among the endocrine cells of the gut the gastrinproducing cell has acquired increasing relevance in the last few years as gastrin appears to be a key factor in the pathogenesis of clinical conditions such as the Zollinger-Ellison syndrome (Gregory, Tracy, French, and Sircus, 1960; Friesen, Tracy, and Gregory, 1962, 1970; McGuigan and Trudeau, 1968; Becker and Seelig, 1969) and a significant percentage of peptic ulcers (Emås and Fyrö, 1964; Bonfils, Dubrasquet, Lewin, and Vatier, 1969; Byrnes, Young, Chisholm, and Lazarus, 1970; Emås, Borg, and Fyrö, 1971; Trudeau and McGuigan, 1971). Furthermore, the human gastrin-producing cell has been recently identified by electron microscopic immunohistochemistry (Greider, Steinberg, and McGuigan, 1972), while the canine gastrin cell has been identified by correlating immunofluorescence with electron microscopy observations (Pearse and Bussolati, 1972). In view of these developments an effort has been made here to correlate light and electron microscopic observations in order to identify this cell type by conventional light microscopy.

\section{Materials and Methods}

Human tissue samples were collected from the mucosa of the gastric corpus, pyloric antrum, and duodenal bulb of 10 subtotal gastrectomy specimens. Five of the patients had chronic peptic gastric ulcer, three had a chronic peptic duodenal ulcer, one had both duodenal and gastric ulcers, and one had an adenocarcinoma of the stomach. For the study of the uninvolved mucosa special care was exercised to avoid areas with ulcer or tumour. Tissues from canine fundic, pyloric, and duodenal mucosa were obtained from several anaesthetized animals.

Tissues were fixed for light microscopy in $10 \%$ buffered formalin, $\mathrm{pH} \mathrm{7,} \mathrm{for} \mathrm{four} \mathrm{to} 10$ days, Zenker-formol for 24 to 48 hours, and Bouin's fixative for 24 hours. The tissues were then dehydrated in graded ethanols, embedded in paraffin, and sections 2 to 6 microns thick were mounted on glass slides. Some sections were stained with modified Masson's trichrome, Gomori's chrome-alum-haematoxylin (Bencosme, 1952), and Herlant's tetrachrome (Herlant, 1960; Kraicer et al, 1967). Regarding the last technique, we have applied a modification of the variant developed by Kraicer and coworkers (1967). Since this was the method of choice and its execution is somewhat critical, it is described in detail here:

1 Fix in Zenker-formol for 24 to 48 hours.

2 Wash in tap water for 12 to 24 hours.

3 Place in $5 \%$ iodine in $90 \%$ ethanol for 12 hours.

4 Dehydrate, embed in paraffin, cut sections 2-4 $\mu$ thick, rehydrate.

5 Wash in running tap water for 30 minutes.

6 Stain in erythrosin solution for two hours Erythrosin B, CI no 773 (Anachemia) $1 \mathrm{~g} ; 0.2 \mathrm{M}$ acetate buffer, pH 6.2 (Walpole) to $100 \mathrm{ml}$.

7 Rinse in distilled water.

8 Stain in Mallory Blue II for five minutes. Stock solution: Aniline Blue, water soluble, Michrome (E. Gurr) $0.5 \mathrm{~g}$; Orange G, CI no. 27 (Anachemia) $2 \mathrm{~g}$; distilled water to $100 \mathrm{ml}$; when dissolved, add $8 \mathrm{ml}$ of glacial acetic acid. To stain dilute with an equal volume of distilled water.

9 Rinse in distilled water. 
10 Stain in acid Alizarine Blue solution for 10 minutes. Acid Alizanine Blue, BB, Michrome no. 9 (E. Gurr) $0.5 \mathrm{~g}$; aluminium sulphate or chloride 10 $\mathrm{g}$; distilled water to $100 \mathrm{ml}$. Boil for three minutes until blue-purple, cool, and bring volume up to $100 \mathrm{ml}$ with distilled water.

11 Rinse in distilled water.

12 Place into $5 \%$ aqueous phosphomolibdic acid for 15 minutes or more.

13 Transfer to $1 \%$ phosphomolibdic acid in $70 \%$ ethanol for four seconds.

14 Transfer to $1 \%$ phosphomolibdic acid in $90 \%$ ethanol for eight seconds.

15 Transfer to absolute alcohol (two changes), clear in toluol and mount.

Other sections were silver impregnated using the methods of Fontana-Masson for argentaffinity (Masson, 1914) and of Hellerström and Hellman (1960) for argyrophilia. Some representative blocks from different regions were serially sectioned to establish correlations between the results obtained with the different techniques, particularly with regard to the gastrin-producing cells.

For electron microscopy tissues were fixed for two hours in cold $3 \%$ glutaraldehyde in $0.1 \mathrm{M}$ phosphate buffer $\mathrm{pH} \mathbf{7 \cdot 2}$. Then they were washed in the same buffer plus $10 \%$ sucrose for two hours and, subsequently, postfixed in $2 \% \mathrm{OsO}_{4}$ for one and a half hours. All reagents contained one drop of $1 \%$ $\mathrm{CaCl}_{2}$ per each $10 \mathrm{ml}$ of solution. The tissues were dehydrated with graded ethanols and embedded in Epon 812. Sections obtained with an LKB ultratome were double-stained with uranyl acetate (Stempak and Ward, 1964) and lead citrate (Venable and Coggeshall, 1965) and photomicrographs were taken with a Hitachi HU $11 \mathrm{C}$ electron microscope.

\section{Results}

Bouin's fixative and $10 \%$ buffered formalin were the fixatives of choice for the silver impregnation of Fontana-Masson while the three fixatives used were adequate for the method of Hellerström and Hellman. Zenker-formol, on the other hand, was the most suitable fixation for the subsequent application of the polychrome stains. In tissues fixed by the latter method, the most rewarding technique for the simultaneous demonstration of the various endocrine cell types of the upper gastrointestinal mucosa was Herlant's tetrachrome. Masson's trichrome was also suitable, while Gomori's chrome-alum-haematoxylin was a distant third choice and will not be discussed further in this paper.

A synopsis of the endocrine cells seen in each of the three regions of the gut is presented in the table. Positive identification is possible only for the $G$ and

\begin{tabular}{|c|c|c|}
\hline Region & Staining Properties ${ }^{1}$ & Cell Type \\
\hline Gastric fundus & $\begin{array}{l}\text { Clear } \\
\text { Brown-yellow } \\
\text { Red (dog only) }\end{array}$ & $\begin{array}{l}\overline{\text { ECL cell }} \\
\text { A-like cell? }\end{array}$ \\
\hline Pyloric antrum & $\begin{array}{l}\text { Bright red (dog) } \\
\text { pink (man) } \\
\text { Brown-yellow } \\
\text { Pale blue }\end{array}$ & $\begin{array}{l}\text { G cell } \\
\text { EC and ECL cells } \\
\text { D-like cell? }\end{array}$ \\
\hline Duodenum & $\begin{array}{l}\text { Golden-yellow } \\
\text { Bright red } \\
\text { Red-purple (man onl } \\
\text { Pale blue }\end{array}$ & $\begin{array}{l}\text { EC cell } \\
\text { D-like cell? }\end{array}$ \\
\hline
\end{tabular}

Table Endocrine cells of human and canine upper gastrointestinal tract

${ }^{1}$ With Herlant's tetrachrome in tissues fixed with Zenker-formol. 'Only tentative for most cells, on the basis of frequency, distribution, and staining properties.

the enterochromaffin cells. Two more tentative identifications are made with regards to the A-like and D-like cells, while the remainder of the cells seen after the polychrome techniques will have to await the establishment of further correlations before they can be identified.

A conspicuous cell type, restricted to the antrum, has a pear-shaped cytoplasm which stains pale pink after Herlant's tetrachrome (fig. 1). These cells stain pale brown after Masson's trichrome. They are believed to be the gastrin-producing cells since they follow the same topographic distribution as those identified by several authors (Bussolati and Pearse, 1970; McGuigan and Greider, 1971; Pearse and Bussolati, 1972) in a number of species using immunohistochemistry. The gastrin cells of the dog are larger and their granules coarser than those of their human counterpart, stain brighter red after Herlant's tetrachrome (fig 2) and darker brown after Masson's trichrome.

When adjacent sections from blocks fixed in Zenker-formol are stained with Herlant's tetrachrome and the Hellerström-Hellman silver technique respectively, the gastrin-producing cells are silver negative. In tissues fixed in $10 \%$ formalin and in Bouin's fixative these cells also appear to be silver negative with the same silver method. In contrast, cells with brown-yellow granules are silver-positive (argyrophilic).

Cells with granules stained golden-yellow after Herlant's tetrachrome (fig 3) and brown-black with Masson's trichrome are noted in small numbers in the human fundus and pylorus and in large numbers in the duodenal mucosa. In the dog these cells are relatively more numerous in the stomach and less conspicuous in the duodenum.

Fontana-Masson's technique for argentaffinity yields small numbers of silver-positive cells in antral and fundic mucosa, whereas the duodenal crypts 


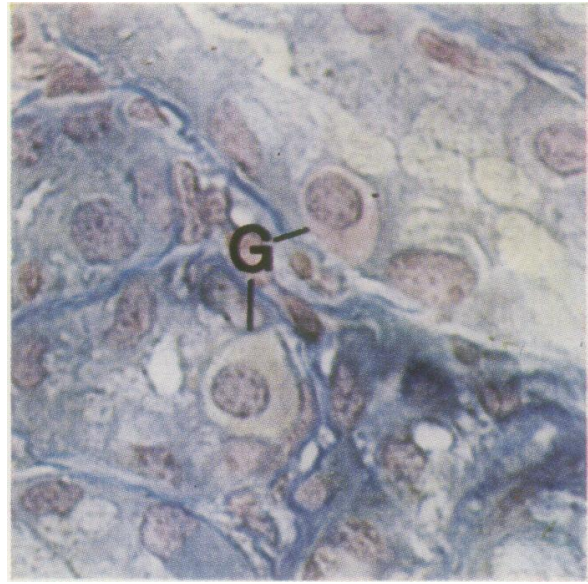

Fig 1

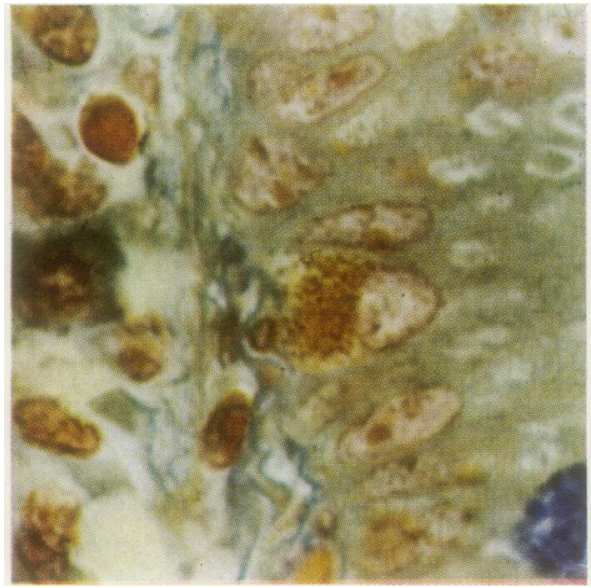

Fig 3

exhibit the presence of significant numbers of these cells. No direct comparison is possible between the results obtained with Herlant's tetrachrome and with Fontana-Masson's silver technique as they require different fixations. Close inspection, however, strongly suggests that those cells containing blackbrown granules after Masson's trichrome and brownyellow (golden-yellow for human duodenum) granules after Herlant's technique correspond to the argentaffin cells on account of their number, shape, and location.

The other cells listed in the table are tentatively considered separate types on the basis of their different tinctorial affinities. The lack of correlation with other techniques at this point, however, renders their definitive identification a subject for further research.

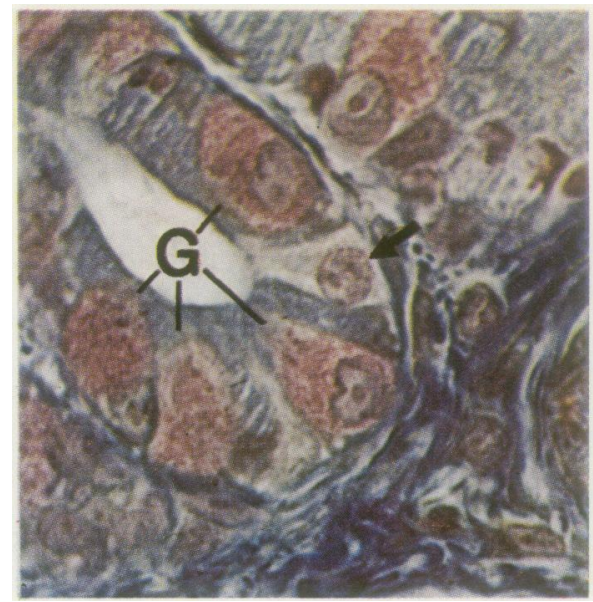

Fig 2

Fig 1 Human antrum. Two pear-shaped gastrinproducing cells possess pink cytoplasm (G). Herlant's tetrachrome. $\times 1000$.

Fig 2 Dog antrum. Several gastrin-producing cells (G) are stained pale red. A triangular cell with pale blue cytoplasmic granule (arrow) is also noted. Herlant's tetrachrome. $\times 1000$.

Fig 3 Human duodenum. A large cell with coarse brown-yellow granules is noted in the centre. Herlant's tetrachrome. $\times 1000$.

The gastrin-producing cells were identified by electron microscopy in both dog and man. Canine gastrin cells are characterized by the presence of numerous round cytoplasmic granules, composed of a well defined limiting membrane which encloses a space either electronlucent or with scanty flocculent material. In man, cells were noted in the antrum identical to those recently identified as gastrinproducing cells by Greider and coworkers (1972) using electron microscopic immunohistochemistry. These cells are characterized by the presence of cytoplasmic granules between 120 and $200 \mathrm{~nm}$ in diameter, a somewhat irregular profile, and possessing a flocculent core of variable electron density (fig 4).

In two patients with chronic peptic ulcer (one gastric and one duodenal) there was marked hyper- 


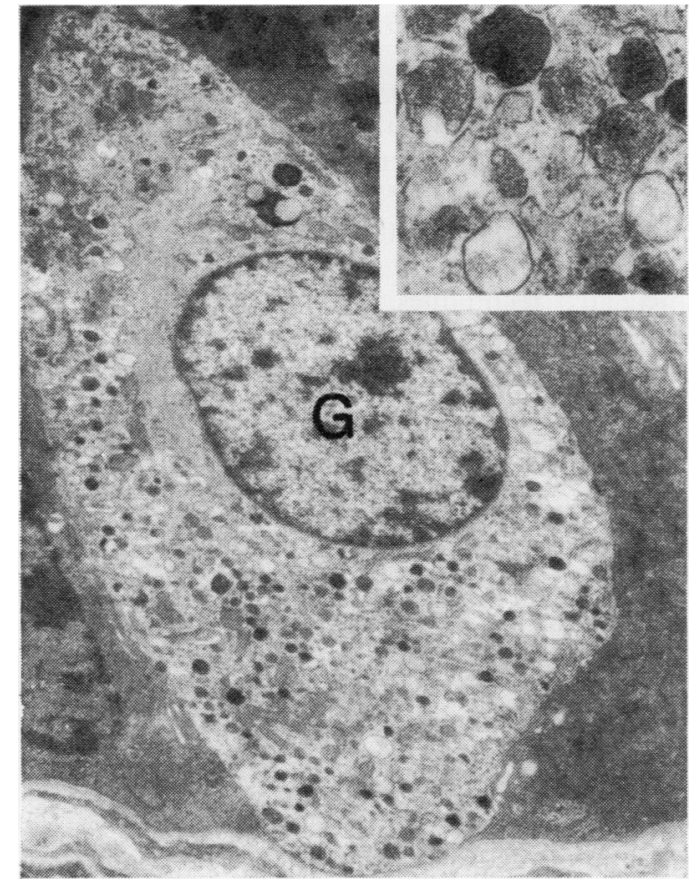

Fig 4 Human antrum. Electron microscopic picture of a gastrin-producing cell (G) containing cytoplasmic granules of variable electron density. Some of these are dark while others have a nearly 'empty' appearance. $\times 6400$.

Inset Close-up view of human G cell granules. $x 26400$.

Fig 5 Human antrum from a patient showing $G$ cell hyperplasia. Five gastrin-producing cells $(G)$ are noted in a cross-section of an antral gland. Pale granules are numerous in these hyperplastic $G$ cells. $\times 6000$.

Fig 4

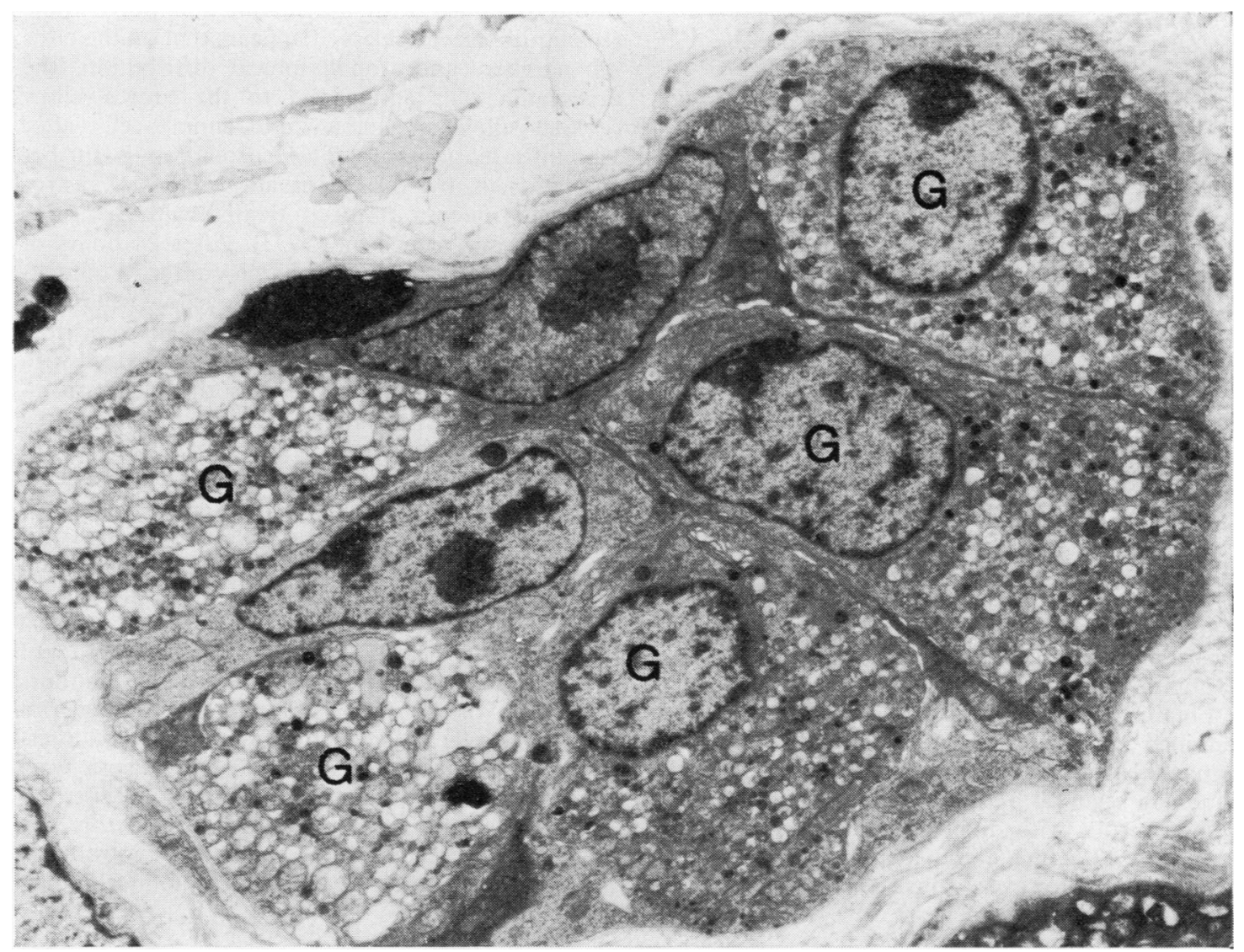

Fig 5 


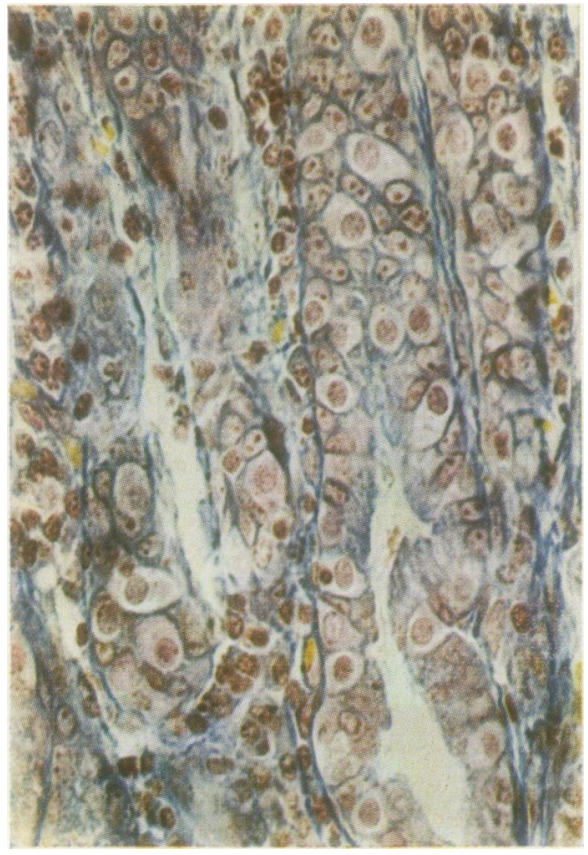

Fig 6 Light microscopic picture of the same antrum described above showing numerous gastrin-producing cells $(G)$. Herlant's tetrachrome. $\times 400$.

plasia of the gastrin-producing cells when observed under electron microscopy (fig 5). When antral tissues from these patients were stained with Herlant's tetrachrome, it was seen that the pale pink cells, purported above to be the gastrin-producing cells, were also markedly increased in number (fig 6).

\section{Discussion}

The main morphological features leading to the identification of the endocrine cells of the gut by light microscopy are: (a) comparatively small size; (b) basal location with respect to the exocrine elements; and (c) the presence of specifically stainable cytoplasmic granules. Herlant's tetrachrome modified by fixation with Zenker-formol has been the most adequate of the methods tried to characterize the various endocrine cell types of the digestive mucosa. It should be emphasized at this point that, in order to obtain satisfactory results with the techniques described here, care must be taken in the performance of the various steps. Polychrome techniques in general require careful 'tailoring' for optimal results with different tissues and even different species. Once these factors are taken into consideration, however, consistent results may be expected. Marked autolysis of the superficial digestive mucosa noted in necropsy specimens not reported here precludes in most cases the attainment of satisfactory results with these polychrome techniques. Unlike histochemical and immunohistochemical approaches, which often require sophisticated techniques, the polychrome methods tested here are essentially simple to perform and can be readily established on a routine basis. In addition, Masson's trichrome and particularly Herlant's tetrachrome, appear to be less controversial than Grimelius' silver technique (Solcia, 1972) and more specific than lead haematoxylin (Pearse and Bussolati, 1972) for the demonstration of the antral gastrin-producing cells. As these techniques allow the simultaneous demonstration of the various endocrine cell types scattered throughout the digestive mucosa, they facilitate the task of evaluating qualitative and/or quantitative changes in tissues from experimental animals and man.

The enterochromaffin cells have been traditionally demonstrated with Fontana-Masson's method for argentaffinity. Unfortunately, this technique cannot be applied to tissues fixed in Zenker-formol, therefore precluding the use of serial sections to compare the results obtained with argentaffin and polychrome techniques. Nevertheless, it appears that on the basis of number and topographical distribution, the argentaffin cells correspond to the brown-yellow (golden-yellow in human duodenum) cells after Herlant's tetrachrome. This correlation is further strengthened by the observation of the gastrointestinal mucosa of dogs treated with reserpine (Lechago and Bencosme, 1973). After 24 hours of treatment the argentaffin cells after FontanaMasson's method and the brown-yellow cells after Herlant's tetrachrome have completely disappeared.

Comparison of serial sections of tissues fixed with Zenker-formol and stained with the HellerströmHellman silver technique and with Herlant's tetrachrome respectively shows that the brownyellow cells are argyrophilic. The gastrin-producing cells, on the other hand, are silver negative after all fixations used. These observations are consistent with those of McGuigan and Greider (1971), who found that the gastrin-producing cells as identified by immunofluorescence were silver negative with a variety of impregnation techniques, including that of Hellerström and Hellman. Lomsky and co-authors (1971), on the contrary, reported that the gastrinproducing cells they identifiied by immunofluorescence in antral as well as duodenal mucosa were silver positive when re-stained with the HellerströmHellman technique. One explanation for this discrepancy is that these different authors introduced modifications in their silver impregnation techniques 
which are not apparent from reading their methodology. Or, alternatively, that their immunohistochemical techniques demonstrate two different types of gastrin-producing cells: one of them would be silver-negative while the other would be silverpositive. The latter possibility seems to find some support from the observations of Bussolati and Pearse (1970). These authors reported that while most of the antral gastrin-producing cells are positive with Grimelius' silver technique for argyrophilia, another group of cells, displaying weaker fluorescence, were silver-negative with the mentioned technique.

The electron microscopic identification of the human antral gastrin-producing cells has been greatly facilitated by the recent work of Greider and co-workers (1972), who showed these cells after immunoperoxidase labelling techniques. Light-electron microscopic correlation in human subjects has been confirmed by the observations reported here of tissues from gastric mucosa with hyperplasia of the gastrin cells seen by both light and electron microscopy.

In the case of the dog, the gastrin cells have been recently identified by electron microscopy in tissues previously treated with immunofluorescence by light microscopy (Pearse and Bussolati, 1972). Reports by others that these cells change their appearance following alcohol infusion (Forssmann and Orci, 1969) or after feeding (Forssmann, Orci, Forssmann, and Rouiller, 1969b) had already suggested their identity. Similarities in topographical distribution when comparing light with electron microscopy of canine antra indicate that the antral red cells after Herlant's tetrachrome are the gastrin-producing cells in this species.

In conclusion, Herlant's tetrachrome as modified in this work is offered as the routine method of choice for the simultaneous recognition of a variety of endocrine cells in the upper gastrointestinal mucosa. This technique is particularly suitable for the identification of the gastrin-producing cell in man as well as in experimental animals. Although the small number of gastrectomy specimens studied in his work precludes the drawing of any meaningful conclusion from the statistical standpoint, it seems apparent from our results that marked gastrin cell hyperplasias can be readily recognized. Quantitative studies of these cells will undoubtedly be relevant to the pathologist, when correlated with pertinent physiological and biochemical data, for a better assessment of patients with disturbed gastric acid secretion. We believe that the introduction of the staining procedures reported here will render this quantitative approach a more easily attainable objective.
This work was supported by grants from the Medical Research Council of Canada and Abbott Laboratories. While engaged in this research project, Dr J. Lechago was the recipient of a fellowship from the Medical Research Council of Canada.

\section{References}

Aures, D., Håkanson, R., and Owman, C. (1970). Formation and storage of amines in endocrine cells of gastric mucosa. $J$. Neuro-visceral Relat., 31, 337-349.

Becker, V., and Seelig, H. P. (1969). Pathologic anatomy and pathophysiology of the Zollinger-Ellison syndrome. In Non-insulin Producing Tumors of the Pancreas. Modern Aspects on ZollingerEllison-Syndrome and Gastrin, edited by L. Demling and R. Ottenjann, pp. 49-64. Thieme, Stuttgart.

Bencosme, S. A. (1952). Studies on the methods of staining the islet cells of the pancreas. A.M.A. Arch. Path., 53, 87-97.

Black, W. C., III (1968). Enterochromaffin cell types and corresponding carcinoid tumors. Lab. Invest., 19, 473.

Black, W. C., III, and Haffner, H. E. (1968). Diffuse hyperplasia of gastric argyrophil cells and multiple carcinoid tumors. An historical and ultrastructural study. Cancer (Philad.), 21, 1080.

Bonfils, S., Dubrasquet, M., Lewin, M., and Vatier, J. (1969). La sécrétion antrale de gastrine dans la physiopathologie des ulcères gastro-dueodénaux. In L'Antre Gastrique, Rapports Présentés aux Journées Françaises de Gastro-Enterologie, pp. 90-105. Masson, Paris.

Bussolati, G., Capella, C., Solcia, E., Vassallo, G., and Vezzadini, P. (1971). Ultrastructural and immunofluorescent investigations on the secretin cell in the dog intestinal mucosa. Histochemie, 26, 218-227.

Bussolati, G., and Pearse. A. G. E. (1970). Immunofluorescent localization of the gastrin-secreting G-cells in the pyloric antrum of the pig. Histochemie, 21, $1-4$.

Byrnes, D. J., Young, J. D., Chisholm, D. J., and Lazarus, L. (1970). Serum gastrin in patients with peptic ulceration. Brit. med. J., 2, 626-629.

Campbell, A. C. P., Gowenlock, A. H., Platt, D. S., and Snow, P. J. D. (1963). A 5-hydroxytryptophan-secreting carcinoid tumour. Gut, 4, 61-67.

Capella, C., Solcia, E., and Vassallo, G. (1969). Identification of six types of endocrine cells in the gastrointestinal mucosa of the rabbit. Arch. Histol. jap., 30, 479-495.

Creutzfeldt, W. (1970). Origin, Chemistry, Physiology and Pathophysiology of the Gastrointestinal Hormones, edited by W. Creutzfeldt, p. 95. Schattauer, Stuttgart and New York.

Cruetzfeldt, W., Arnold, R., Creutzfeldt, C., Feurle, G., and Ketterer, H. (1971). Gastrin and G-cells in the antral mucosa of patients with pernicious anaemia, acromegaly and hyperparathyroidism and in a Zollinger-Ellison tumour of the pancreas. Europ. $J$. clin. Invest., 1, 461-479.

Emås, S., Borg, I., and Fyrö, B. (1971). Antral and duodenal gastrin activity in non-ulcer and ulcer patients. Scand. J. Gastroent., 6, $39-43$.

Emås, S., and Fyrö, B. (1964). Antral gastrin activity in duodenal and gastric ulcers. Gastroenterology, 46, 1-7.

Forssmann, W. G. (1970). Ultrastructure of hormone-producing cells of the upper gastrointestinal tract. In Origin, Chemistry, Physiology and Pathophysiology of the Gastrointestinal Hormones, edited by W. Creutzfeldt, pp. 31-70. Schattauer, Stuttgart and New York.

Forssmann, W. G., and Orci, L. (1969). Ultrastructure and secretory cycle of the gastrin-producing-cell. $Z$. Zellforsh. mikroskop. Anat., 101, 419-432.

Forssmann, W. G., Orci, L., Pictet, R., Renold, A. E., and Rouiller, C. (1969a). The endocrine cells in the epithelium of the gastrointestinal mucosa of the rat. J. Cell Biol., 40, 692-715.

Forssmann, W. G., Orci, L., Forssmann, W., and Rouiller, C. (1969) On the problem of the gastrin-producing cell. In Non-insulin Producing Tumors of the Pancreas. Modern Aspects on ZollingerEllison-Syndrome and Gastrin, edited by $\mathrm{L}$. Demling and R. Ottenjann, pp. 82-85. Thieme, Stuttgart.

Friesen, S. R., Bolinger, R. E., Pearse, A. G. E., and McGuigan, J. E. (1970). Serum gastrin levels in malignant Zollinger-Ellison syndrome after total gastrectomy and hypophysectomy. Ann. Surg., 172, 504-521. 
Friesen, S. R., Tracy, H. J., and Gregory, R. A. (1962). Mechanism of the gastric hypersecretion in the Zollinger-Ellison syndrome: successful extraction of gastrin-like activity from metastases and primary pancreatico-duodenal islet cell carcinoma. Ann. Surg., 155, 167-174.

Gregory, R. A., Tracy, H. J., French, J. M., and Sircus, W. (1960). Extraction of a gastrin-like substance from a pancreatic tumour in a case of Zollinger-Ellison syndrome. Lancet, 1, 1045-1043.

Greider, M. H., Steinberg, V., and McGuigan, J. E. (1972). Electron microscopic identification of the gastrin cell of the human antral mucosa by means of immunocytochemistry. Gastroenterology, 63, 572-583.

Grossman, M. I. (1968). Gastrointestinal hormones. Med. Clin., 52, 1297-1303.

Håkanson, R. (1970). New aspects of the formation and function of histamine, 5-hydroxytryptamine and dopamine in gastric mucosa. Acta physiol. scand., Suppl. 340.

Håkanson, R., Owman, C., Sporrong, B., and Sundler, F. (1971). Electron microscopic classification of amine-producing endocrine cells by selective staining of ultra-thin sections. Histochemie, 27, 226-242.

Hellerström, C., and Hellman, B. (1960). Some aspects of silver impregnation of the islets of Langerhans in the rat. Acta endocr. (Kbh.), 35, 518-532.

Herlant, H. (1960). Etude critique de deux techniques nouvelles destincés a metre en evidence des differents catégories céllularies présent dans la gland pituitaire. Bull. Micr. appl., 10, 3744.

Kraicer, J., Herlant, M., and Duclos, P. (1967). Changes in adenohypophyseal cytology and nucleic acid content in the RA 32 days after bilateral adrenalectomy and the chronic injection of cortisol. Canad. J. Physiol. Pharmacol., 45, 947-956.

Lechago, J., and Bencosme, S. A. (1973). The endocrine elements of the digestive system. In International Revic $w$ of Experimental Pathology, edited by G. W. Richter and M. A. Epstein, Vol. 12, pp. 119-201. Academic Press, New York.

Lomský, R., Langr, F., and Vortel, V. (1971). Immunofluorescent demonstration of gastrin and glucagon in man. In Immunological Methods in Endocrinology, edited by K. Federlin, C. N. Hales, and J. Kaacht, pp. 14-17. Thieme, Stuttgart. Academic Press, New York and London.

Masson, P. (1914). La glande de l'intestin chez l'homme. C.R. Soc. Biol. (Paris), 158, 59-61.

McGuigan, J. E., and Greider, M. H. (1971). Correlative immunochemical and light microscopic studies of the gastrin cell of the antral mucosa. Gastroenterology, 60, 223-236.

McGuigan, J. E., and Trudea 1, W. L. (1968). Immunochemical measurement of elevated levels of gastrin in the serum of patients with pancrcatic tumors of the Zollinger-Ellison variety. New Engl. J. Med., 278, 1308-1313.

Oberhelman, H. A., Jr., Nelsen, T. S., Johnson, A. N., Jr., and Dragstedt, L. R. (1961). Ulcerogenic tumors of the duodenum. Ann. Surg., 153, 214-227.

Pearse, A. G. E. (1968). Common cytochemical and ultrastructural characteristics of cells producing polypeptide hormones (the APUD series) and their relevance to thyroid and ultimobranchial C cells and calcitonin. Proc. roy. Soc. B, 170, 71-80.

Pearse, A. G. E., and Bussolati, G. (1970). Immunofltorescence studies of the distribution of gastrin cells in different clinical states. Gut, 11, 646.

Pearse, A. G. E., and Bussolati, G. (1972). The identification of gastrin cells as G. cells. Virchows Arch. path. Anat., 355, 99-104.

Pearse, A. G. E., Coulling, I., Weavers, B., and Friesen, S. (1970). The endocrine polypeptide cells of the human stomach, duodenum, and jejunum. Gut, 11, 649-658.

Polak, J. M., Bloom, S., Coulling, I., and Pearse, A. G. E. (1971a) Immunofluorescent localization of enteroglucagon cells in the gastrointestinal tract of the dcg. Gut, 12, 311-318.

Polak, J. M., Bloom, S., Coulling, 1., and Pearse, A. G. E. (1971b) Immunofluorescent localization of secretin in the canine duodenum. Gut, 12, 605-610.

Polak, J. M., Bussolati, G., and Pearse, A. G. E. (1971c). Cytochemical, immunofluorescence and ultrastructural investigations of the antral $\mathbf{G}$ cells in hyperparathyroidism. Virchows Arch. [Zellpath.], 9, 187-197.

Polak, J. M., Coulling, I., Doe, W., and Pearse, A. G. E. (1971d). The $G$ cells in pernicious anaemia. Gut, 12, 319-323.

Rubin, W. (1969). Proliferation of endocrine-like (enterochromaffin) cells in atrophic gastric mucosa. Gastroenterology, 57, 641-648.

Sandler, M., and Snow, P. J. D. (1958). An atypical carcinoid tumou secreting 5-hydroxytryptophan. Lancet, 1, 137-139.

Sasagawa, T., Kobayshi, S., and Fujita, T. (1970). The endocrine cells in the human pyloric antrum. An electron microscope study of biopsy materials. Arch. Histol. jap., 32, 275-288.

Soga, J., and Tazawa, K. (1971). Pathologic analysis of carcinoids. Histological reevaluation of 62 cases. Cancer (Philad.), 28, 990 998.

Solcia, E. (1972). The gastrin cell and the secretin cell. Rendic. R. Gastroent., 4, 22.

Solcia, E., Capella, C., and Vassallo, G. (1970b). Endocrine cells of the stomach and pancreas in states of gastric hypersecretion. Rendic. R. Gastroent., 2, 147-158.

Solcia, E., Vassallo, G., and Capella, C. (1970a), Cytology and cytochemistry of hormone producing cells of the upper gastrointestinal tract. In Origin, Chemistry, Physiology and Patho physiology of the Gastrointestinal Hormones, edited by W. Creutzfeldt, pp. 3-29. Schattauer, Stuttgart and New York.

Stempak, J. G., and Ward, R. T. (1964). An improved staining method for electron microscopy. J. Cell Biol., 22, 697-701.

Thompson, J. C., Hirose, F. M., Lemmi, C. A. E., and Davidson, W. D. (1968). Zollinger-Ellison syndrome in a patient with multiple carcinoid-islet cell tumors of the duodenum. Amer. J. Surg., 115, 177-184.

Trudeau, W. L., and McGuigan, J. E. (1971). Relations between serum gastrin levels and rates of gastric hydrochloric acid secretion. New Engl. J. Med., 284, 408-412.

Vassallo, G., Capella, C., and Solcia, E. (1971b). Endocrine cells of the human gastric mucosa. Z. Zellforsch. 118, 49-67.

Vassallo, G., Solcia, E., and Capella, C. (1969). Light and electron microscopic identification of several types of endocrine cells in the gastrointestinal mucosa of the cat. Z. Zellforsch. mikroskop. Anat., 98, 333-356.

Venable, J. H., and Coggeshall, R. (1965). A simplified lead citrate stain for use in electron microscopy. J. Cell Biol., 25, 407408.

Williams, E. D., and Sandler, M. (1963). The classification of carcinoid tumours. Lancet, 1, 238-239. 